\title{
Perilaku Penemuan Informasi Mahasiswa Shopaholic tentang Fashion di Surabaya
}

\section{Information Searching Behaviour About Fashion in Shopaholic Students in}

\author{
Surabaya \\ Yuniar Dwi Puspitasari \\ yuniar.dwi.puspitasari-2015@ fisip.unair.ac.id \\ Mahasiswa Program Studi Ilmu Informasi dan Perpustakaan, Fakultas Ilmu Sosial \\ dan Ilmu Politik, Universitas Airlangga
}

\begin{abstract}
Information about fashion is an activity that is intended to find information about fashion that you want to know. Information discovery activities are not only to fulfill the information needs but also to increase students' knowledge about fashion. In information discovery activities students can obtain information on the internet such as social media, websites, markets, and on television. But in the process of finding information there are still quite a lot of students who experience obstacles and constraints ranging from accessing to purchasing something. Regarding fashion, it is very pleasing to lifestyle, where fashion can be the identity, features, or differences of the individual's expression. Besides that, a person's lifestyle will draw attention to the situation and realize it or not will make a person have a hedonic nature or often called consumptive. This research uses descriptive quantitative. This study uses the Everyday Life Information Seeking Behavior theory by Reijo Savolainen (1995). The research location was conducted at the University in Surabaya, namely at Airlangga University, PERBANAS, Surabaya University, and Surabaya State University. The sampling method uses purposive sampling with a total of 100 respondents. The results of the study show the facts about students who find fashion information most often sought is clothing as much as $70 \%$ with an average duration of 1-2 hours at night. Besides that, the habit of meeting the desired information needs is accessing an idol figure and also viewing photos/videos on social media $82 \%$. The second is shopaholic student information source preferences in finding information needed by students using smartphones to access Instagram social media. And information sources used to find information are $75 \%$ handpicked information sources. Related to problems in information discovery. Where shopaholic students who spent the information found $63 \%$, related to the information obtained related to product/product information as much as $58 \%$. The mode search information that was carried out was fulfilled by carrying out the activity of searching again by using the free and relevant source of information.
\end{abstract}

Keywords: Information discovery behavior, students, fashion, lifestyle

\begin{abstract}
Abstrak
Perilaku penemuan informasi fashion merupakan suatu kegiatan yang bertujuan untuk menemukan informasi tentang fashion yang ingin diketahui. Aktivitas penemuan informasi tersebut selain untuk memenuhi kebutuhan informasi juga dengan tujuan untuk menambah pengetahuan mahasiswa tentang fashion. Dalam aktivitas penemuan informasi mahasiswa bisa mendapatkan informasi di internet seperti media sosial, website, market place maupun di televisi. Namun dalam proses penemuan informasi masih cukup banyak mahasiswa yang mengalami hambatan dan kendala mulai dari pengaksesan sampai dengan pembelian barang. Berbicara tentang fashion erat kaitannya dengan gaya hidup, dimana fashion bisa menjadi identitas, ciri, atau gambaran atas ekspresi individu tersebut. Disamping itu, gaya hidup seseorang akan berpengaruh pada perilaku dan disadari atau tidak akan membuat seseorang memiliki sifat hedonis atau sering disebut konsumtif. Penelitian ini menggunakan metodologi kuantitatif deskriptif. Penelitian ini menggunakan teori Everyday Life Information Seeking Behaviour oleh Reijo Savolainen (1995). Lokasi penelitian yaitu dilakukan di empat Universitas di Surabaya, yaitu di Universitas Airlangga, PERBANAS, Universitas Surabaya, dan Universitas Negeri Surabaya. Metode pengambilan sampel menggunakan purposive sampling dengan jumlah 100 responden. Hasil dari penelitian menunjukkan bahwa kebiasaan mahasiswa dalam penemuan informasi fashion yang paling sering dicari yaitu pakaian sebanyak 70\% dengan rata-rata durasi 1-2 jam pada malam hari. Disamping itu
\end{abstract}


kebiasaan dalam memenuhi kebutuhan informasi yang diinginkan yaitu mengakses sosok idola dan juga melihat foto/video di media sosial $82 \%$. Yang kedua yaitu preferensi sumber informasi mahasiswa shopaholic dalan penemuan informasi mayoritas mahasiswa menggunakan smartphone, untuk mengakses media sosial instagram. Dan mayoritas sumber informasi yang digunakan untuk melakukan penemaun informasi ialah sumber informasi yang dipilih sendiri $75 \%$. Yang ketiga terkait penyelesaian masalah dalam penemuan informasi. Dimana mahasiswa shopaholic yang mengalami kendala dalam penemuan informasi terdapat $63 \%$, mayoritas bentuk kendala yang pernah dialami yaitu terkait informasi barang/produk sebanyak 58\%. Hasil penelusuran informasi fashion yang dilakukan mayoritas terpenuhi dengan melakukan kegiatan pencarian ulang dengan menggunakan sumber informasi yang gratis dan relevan.

Kata kunci : Perilaku penemuan informasi, mahasiswa, fashion, gaya hidup

\section{Pendahuluan}

Informasi dalam era globalisasi seperti saat ini sudah menjadi bagian yang penting dalam kehidupan. Tak terkecuali di kalangan mahasiswa, terlebih yang memiliki kegemaran untuk berbelanja seperti fashion misalnya. Dalam berbelanja, mahasiswa juga membutuhkan informasi untuk mendukung kegiatannya tersebut. Untuk memenuhi kebutuhan informasi tersebut suatu individu akan melakukan penemuan informasi untuk memperoleh informasi terkait sesuatu hal yang ingin mereka ketahui. Hal seperti ini dibutuhkan oleh mahasiswa shopaholic yakni dengan tujuan untuk mendapatkan informasi tentang fashion, termasuk barang yang akan dibeli, sehingga sebelum membeli suatu barang mahasiswa sudah mengetahui seperti apa barang yang akan dibeli. Misalnya, penemuan informasi terkait barang fashion yang akan dibeli, mahasiswa mencari informasi tentang barang tersebut diantaranya seperti terbuat dari bahan apa, warna yang tersedia apa saja, ukuran, kegunaan dan juga harga dari barang tersebut. Informasitersebutbiasanyadidapatkandarisosialmedia, pasar digital, media masa yang menanyajikan informasi terkait fashion. Sehingga sebelum berbelanja mahasiswa shopaholic akan mengetahui informasi tentang barang yang akan mahasiswa beli di internet..

Dengan kemajuan tekologi seperti saat ini, tentunya mempermudah mahasiswa dalam menjalankan aktivitas mereka, dimana mereka bisa mendapatkan informasi dari berbagai macam sumber, dan jangkauannya pun juga lebih luas. Saat ini dalam memperoleh informasi masyarakat lebih banyak memilih internet sebagai referensi yang mereka gunakan, yang mana di internet informasi yang diberikan sangat bervariasi dan dari berbagai macam sumber informasi. Dari banyaknya sumber informasi yang tersedia, masing-masing individu biasanya memiliki preferensi sumber informasi sendiri yang menurut mereka bisa dipercaya dan sering mereka gunakan. Hal ini juga terjadi di kalangan mahasiswa, dimana setiap mahasiswa memiliki sumber informasi sendiri yang mereka pilih (preferensi) dan mereka gunakan untuk memenuhi kebutuhan informasi mereka seperti media sosial, blog, web, market place dan lain sebagainya. Hal ini sesuai dengan hasil survey yang dilakukan oleh APJII tahun 2017 yang mengatakan bahwa pengguna internet di kalangan mahasiswa tinggi yaitu S1/diploma sebesar 79,23\% dan S2/S3 mencapai 88,24\%, dengan penggunaan media sosial mencapai angka yaitu $87,13 \%$, search engine $74,84 \%$, lihat foto $72,79 \%$, lihat video $69,64 \%$, download video 70,23\%, download gambar 56,77\%, artikel 55,30\%, upload file $35,99 \%$, e-mail 33,58\%, beli barang $32,19 \%$, pendaftaran 16,97 , jual barang $8,12 \%$.

Ditambah lagi dengan sifat mahasiswa yang bisa dikatakan fase pencarian jati diri berlangsung, yang di masa inilah mahasiswa sedang menggebu-gebunya dan memiliki semangat yang tinggi dalam menemukan jati diri mereka yaitu salah satunya dengan memperbaiki fashion dan gaya hidup mereka. Karena gaya hidup seseorang akan berpengaruh pada perilaku dan bahkan memunculkan sikap konsumtif seseorang. Sesuai dengan Chaney (dalam Hendraningrum (2004)), yang mengatakan bahwa bagi masyarakat modern life style atau gaya hidup seseorang menggambarkan atas sikap, kekayaan, nilai-nilai dan juga posisi sosial orang tersebut. Sehingga, secara disadari atau tidak akan membuat seseorang memiliki sifat hedonis atau sering disebut konsumtif, dimana orang tersebut memiliki ketertarikan yang lebih untuk berbelanja dan membeli barang- barang yang diinginkan yang mengakibatkan orang tersebut akan merasa senang. Hal ini sesuai dengan Subandi (2011) perilaku konsumtif merupakan gambaran adanya gaya hidup 
atau pola hidup seseorang yang dikendalikan dan didorong oleh suatu keinginan untuk memenuhi hasrat kesenangan semata. Ketertarikan akan berbelanja yang berlebih inilah yang apabila dilakukan terus menerus akan mengakibatkan seseorang menjadi orang yang sangat menyukai belanja atau yang biasa disebut dengan shopaholic. Hal ini di dukung dengan pernyataan Moussa (dalam Ceballos, 2010), yang menyatakan bahwa shopaholics di Inggris meningkat yang disebabkan karena perempuan Inggris banyak yang menjadi penggemar setia dari baju atau pakaian.

Dengan kemajuan teknologi saat ini menjadi pilihan dan sangat dimanfaatkan, mengingat kota Surabaya sebagai kota metropolitan terbesar kedua di Indonesia. Melihat hal tersebut disadari atau tidak berpengaruh terhadap gaya hidup mereka, yang sehingga akan cenderung membentuk perilaku konsumtif dengan kegiatan berbelanja yang terlalu sering. Sehingga dengan begitu akan semakin mendorong mahasiswa untuk melakukan penemuan-penemuan informasi yang lebih tentang fashion yang dimana informasi-informasi tersebut akan mereka dapatkan melalui berbagai macam sumber, sehingga fenomena tersebut menjadi menarik untuk diteliti.

Penelitian tentang perilaku penemuan informasi tentang fashion di kalangan mahasiswa shopaholic sebagai gaya hidup hedonisme di Surabaya belum pernah dilakukan. Namun penelitian tentang perilaku penemuan informasi tentang fashion di kalangan remaja putri surabaya sudah pernah dilakukan tetapi penelitian ini hanya mengkaji terkait penemuan informasi di kalangan remaja putri saja. Penelitian yang pernah dilakukan tersebut yaitu penelitian Siska Apriliana Endang Purwanti (2017) yang berjudul "Perilaku Penemuan Informasi Tentang Fashion Di Kalangan Remaja Putri Surabaya". Dari hasil penelitian tersebut menunjukkan bahwa dalam melakukan penemuan informasi tentang fashion di kalangan remaja putri Surabaya dipengaruhi oleh kesenjangan kelas sosial yang mengakibatkan remaja putri memerlukan pengaturan waktu untukmelakukannya.

\section{Metode Penelitian}

Penelitian ini menggunakan pendekatan kuantitatif dengan tipe deskriptif. Tujuan dari penelitian deskriptif adalah untuk menggali dan menguraikan mengenai suatu fenomena sosial, dengan cara mendeskripsikan beberapa variabel yang berkenaan dengan masalah yang diteliti. Penelitian ini ditekankan pada mahasiswa shopaholic dengan gaya hidup hedonisme. Lokasi dari penelitian ini di Kota Surabaya. Fokus lokasi dari penelitian ini yaitu di Perguruan Tinggi yang ada di Surabaya. Karena adanya keterbatasan waktu, dengan demikian penelitian ini dilakukan secara acak dan muncul 4 nama Perguruan Tinggi yang akan menjadi tempat penelitian yaitu : Universitas Airlangga, Universitas Surabaya, STIE Perbanas dan Universitas Negeri Surabaya.

\section{Pembahasan}

\section{Kebiasaan Shopaholic dalam Penemuan Informasi tentang Fashion}

Kebiasaan dalam penemuan informasi merupakan suatu bentuk kegiatan yang sering dilakukan mahasiswa untuk menuju target atau tujuan yang ingin dicapai yaitu dalam hal ini melakukan penemuan informasi tentang fashion. Menurut Hutabarat (dalam Aunurrahman (2009:187)) bahwa kebiasaan ialah kegiatan yang dilakukan secara berulang kali dan secara otomatis kegiatan tersebut menjadi berlangsung secara terus menerus tanpa menunggu adanya perintah terlebih dahulu. Kebiasaan mahasiswa shopaholic diantaranya yaitu tentang intensitas mahasiswa shopaholic dalam melakukan kegiatan penemuan informasi fashion, jenis kegiatan yang sering dilakukan mahasiswa dalam penemuan informasi fashion, tujuan mahasiswa shopaholic melakukan penemuan informasi fashion, alasan mahasiswa shopaholic melakukan penemuan informasi fashion, serta cara yang dilakukan mahasiswa shopaholic untuk menemukan informasi fashion.

Kebiasaan mahasiswa shopaholic dalam kegiatan penemuan informasi, yaitu dari intensitas mengakses sosok idola yang fashion stylenya dijadikan sebagai referensi. Data pada menunjukkan, sebanyak $22 \%$ atau sejumlah 22 mahasiswa melakukan kegiatan pengaksesan sosok yang menjadi idolanya setiap hari. Sebanyak $20(20 \%)$ mahasiswa memilih mengakses sosok yang menjadi idolanya tersebut sebanyak 3-4 kali dalam kurun waktu satu minggu. Kemudian mahasiswa yang memilih mengakses sosok idolanya tersebut lebih dari 5 kali dalam satu minggu yaitu sebanyak 
12 (12\%) mahasiswa. Sedangkan sebanyak 46 mahasiswa memilih untuk mengakses sosok idolanya 1-2 kali dalam satu minggu. Hasil dari data diatas menunjukkan bahwa mayoritas dari mereka melakukan aktivitas pengaksesan terhadap sosok idola 1-2 kali dalam seminggu, karena mahasiswa juga mengakses informasi fashion lainnya meskipun memiliki sosok idola. Hal ini dilakukan sebagai penyeimbang sekaligus sebagai informasi tambahan mengenai fashion. Karena seperti yang diketahui bahwa fashion public figure, influencers, designer memiliki gaya fashion yang menarik-menarik dan bermacam-macam, mengingat profesi mereka sangat penting untuk memperhatikan fashion mereka karena profesi mereka selalu menjadi sorotan. Oleh karena itu, fashion sangat mereka perhatikan dan layak apabila banyak mahasiswa yang memiliki idola seperti mereka. Terlebih bagi designer yang secara profesi memang sudah menjadi tugasnya untuk mebuat dan mendesain fahion terutama dalam pakaian.

Tingkat keseringan mahasiswa dalam mengakses informasi selain sosok yang diidolakan sebagai kebiasaan mahasiswa dalam mencari referensi tentang fashion. Sebanyak 59 (59\%) mahasiswa melakukan penelusuran informasi sewaktu-waktu, setiap kali mereka menginginkan informasi. Sedangkan 15 (15\%) mahasiswa akan melakukan penelusuran pada saat akan melakukan aktivitas berbelanja saja dengan alasan sebagai referensi sebelum membeli. Selain itu $17 \%$ atau sebanyak 17 mahasiswa memilih untuk melakukan penelusuran informasi ketika akan menghadapi suatu momen atau acara saja, seperti misalnya ketika akan menghadiri di pernikahan teman misalnya. Dan berbeda dengan 9 (9\%) mahasiswa dimana mereka akan melakukan kegiatan penelusuran informasi fashion pada saat mempunyai uang lebih. Berdasarkan data tersebut dapat ditarik kesimpulan bahwa sebagian besar mahasiswa shopaholic di Surabaya mengatakan bahwa mereka akan melakukan kegiatan penemuan informasi sewaktu-waktu. Sehingga tidak harus menunggu ketika akan menghadapi momen tertentu, ketika mempunyai uang lebih maupun pada saat akan melakukan aktivitas berbelanja saja. Karena penelusuran informasi itu sah-sah saja untuk dilakukan kapan pun selain untuk mengetahui tentang fashion yang sedang in juga untuk menambah pengetahuan dan wawasan mereka.

Masih membahas tentang intensitas, kali ini berkaian dengan waktu dan durasi dalam aktivitas penemuan informasi. Dari keseluruhan 100 mahasiswa, sebanyak 73 (73\%) mahasiswa lebih memilih di waktu malam hari. Sedangkan 26 hari lainnya memilih waktu siang/ sore hari, dan 1 mahasiswa sisanya memilih di waktu pagi hari. Berdasakan dari data tersebut menunjukkan bahwa mayoritas mahasiswa memilih untuk melakukan penemuan informasi pada malam hari, karena menurut mereka di malam hari merupakan waktu yang tepat untuk melakukan penemuan informasi fashion. Karena pada malam hari sambal santai menjelang tidur dan dengan pikiran yang sudah membaik tidak terlalu banyak yan dipikirkan. Selain itu dengan melihat- lihat fashion bisa untuk membuat refresh otak dengan melihat outlook yang bagus- bagus. Sedangkan di siang hari bisa dibilang di siang/sore hari masih ribet karena masih berada di jam-jam produktif, atau mungin juga masih sibuk dengan kesibukanny. Oleh karena itu tidak banyak yang memilih di iang/ sore hari untuk melakukan penemuan informasi. Dengan durasi paling banyak 1-2 jam untuk menemukan informasi fashion yang dibutuhkan yaitu sebanyak 45\%. Selanjutnya mahasiswa yang menghabiskan waktu $<1$ jam yaitu sebanyak $40(40 \%)$ mahasiswa. Kemudian dengan durasi yang cukup lama yaitu 3-4 jam dibutuhkan oleh 10 (10\%) mahasiswa. Dan sebanyak 5 (5\%) mahasiswa membutuhkan durasi waktu sebanyak $>4$ jam untuk mendapatkan informasi fashion yang dibutuhkan. Sehingga dari data tersebut menunjukkan bahwa mayoritas mahasiswa membutuhkan waktu 1-2 jam untuk melakukan kegiatan penemuan informasi fashion Karena menurut mereka dengan waktu 1-2 jam itu mrupakan waktu yang pas tidak terlalu cepat dan juga tidak terlalu lama. Sedangkan mahasiswa yang mmerlukan waktu yang cukup lama mungkin saja mereka melakukan penemuan informasi yang sangat banyak dan rumit sehingga mereka memerlukan waktu lebih yang cukup panjang untuk menemukan informasi sesuai dengan apa yang dibutuhkan.

Bentuk kegiatan mahasiswa shopaholic dalam memenuhi kebutuhan informasi yang diinginkan. sebanyak 4 (4\%) mahasiswa lebih memilih dengan cara mendownload video-video yang memberikan informasi tentang cara mix and match outfit yang tepat. Selain itu terdapat juga 4 (4\%) mahasiswa lainnya yang memilih membaca artikel tentang fashion untuk memenuhi kebutuhan informasi yang diinginkan. dan sebanyak $10(10 \%)$ mahasiswa lebih memilih untuk mendownloaad gambar atau foto. Berbeda lagi dengan $82(82 \%)$ mahasiswa lainnya yang memilih untuk hanya sekedar melihat saja foto maupun video di media social dalam memenuhi kebutuhan informasi yang diinginkan. Sehingga bisa dikatakan bahwa mayoritas mahasiswa memilih untuk hanya sekedar melihat foto atau video di media social. Karena dengan melihat foto atau video saja mereka sudah bisa tahu dari bentuk visualnya, Berbeda dengan artikel kita harus membaca dan memahami terlebih dahulu. Sedangkan mendownload foto/video harus menyediakan space banyak mengingat video 
secara ukuran cukup besar dan memerlukan kuota internet yang cukup banyak.

Hal tersebut sesuai yang dikatakan oleh mahasiswa dari Universitas Negeri Surabaya, dimana mahasiswa tersebut menyampaikan bahwa mahasiswa lebih memilih untuk melihat-lihat foto atau video tentang fashion di media social saja, yaitu :

". ya kalo bisa diliat sepanjang waktu atau kapanpun bisa kenapa harus didonlotmbak, kan kalo download juga makan kuota, makan memori, atau mungkin kalo takut ilang sekarang bisa di screenshoot tanpa harus di download "

\section{Preferensi Sumber Informasi Shopaholic dalam Penemuan Informasi}

Preferensi sumber informasi merupakan sumber informasi yang lebih dipercaya dan sering yang digunakan oleh mahasiswa shopaholic sebagai pedoman atau acuan dengan tujuan untuk mendukung kegiatan sehari-hari dalam menemukan informasi tentang fashion. Sedangkan menurut Salvatore (1991:126) preferensi memiliki keterkaitan dengan kemampuan pengguna dalam menata pilihan-pilihan supaya bisa digunakan untuk menentukan pilihan. Seperti halnya dalam kegiatan penemuan informasi fashion ini yang mana mereka dihadapkan dengan berbagai macam sumber informasi.

Dari hasil penelitian menunjukkan tentang jenis perangkat yang digunakan untuk melakukan kegiatan penemuan informasi, jenis informasi fashion yang dibutuhkan mahasiswa shopaholic, alasan mahasiswa shopaholic menggunakan sumber informasi yang dipilih dalam kegiatan penemuan informasi tentang fashion, jenis aplikasi yang digunakan untuk menunjang kegiatan penemuan informasi fashion, dan frekuensi penggunaan sumber informasi dalam kegiatan penemuan informasi.

Adapun pada preferensi sumber informasi shopaholic dalam penemuan informasi, yaitu pada tabel 3.16 mengenai jenis perangkat yang paling sering digunakan mahasiswa adalah smartphone yang berjumlah 99\% atau 99 mahasiswa, dan sisanya 1 mahasiwa memilih menggunakan laptop. Yang mana berarti hampir semua mahasiswa memilih menggunakan smartphone untuk melakukan kegiatan penemuan informasi fashion. Dengan alasan karena smartphone lebih fleksibel dan juga ringan sehingga mudah untuk dibawa- bawa. Sedangkan laptop secara fisik terlalu besar dn berat sehingga susah untuk dibawa, dan selain itu laptop juga sangata makan tempat sehingga memerukan space yang cukup besar. Hal ini sesuai dengan data dari (wearesocial, hootsuite, 2018) yang dari hasil survey menemukan sejumlah 177,9 juta atau $67 \%$ dari jumlah populasi. Selain itu dipertegas juga oleh mahasiswa asal universitas airlangga yang mengatakan :

“.... Enak pake $h p$, bias langsung gitu mbak, kan $h p$ sekarang pasti ada internetnya, lagian kita juga pasti lebih sering pegang hp daripada laptop kan, jadi kalo pas kepikiran apa gitu langsung aja search, kalo mesti nyalaain laptop keburu lupa tadi pengen search tentang apaan hehe...." - UNAIR

Dari penelitian ini, diketahui $89(89 \%)$ mahasiswa lebih memilih menggunakan media social untuk menemukan informasi, 8 (8\%) memilih mengunjungi blog/website resmi, 2 (2\%) mahasiswa memilih menggunakan majalah online, dan sisanya $1 \%$ atau 1 orang mahasiswa memilih televisi untuk menemukan informasi. Dari data diatas bisa diketahui bahwa minat mahasiswa terhadap media sosial sangat tinggi, terlihat dari jumlah mahasiswa yang memilih media social sebagai sumber informasi mereka, daripada sumber infomasi lainnya. Sesuai dengan data survei (dari wearesocial, hoosuite, 2018) bahwa jumlah pengguna aktif media sosial per Januari 2018 adalah 130 juta jiwa. Hal ini karena media social saat ini sangat di gandrungi oleh kaum muda dengan informasi-informasi yang diberikan ditambah lagi dengan adanya fitur-fitur uniknya sehingga tidak monoton. Sedangkan blog/website resmi banyak menampilkan tulisan-tulisan yang terkadang membuat cepat bosan apabila tidak dikemas dengan baik. Dan pemilihan majalah online ini kurang diminati karena kurang familiar dan kurang banyak yang tahu, berbeda sekali dengan televisi sebagai sumber informasi pilihan mengingat di televisi program tentang fashion memang ada tetapi tidak selalu ada, tidak bisa digunakan sebagai sumber informasi yang setiap saat diperlukan.

Media sosial menjadi platform yang paling sering digunakan untuk mendapatkan informasi fashion yaitu sebanyak $80 \%$ atau 80 mahasiswa. Sedangkan sisanya 11 mahasiswa atau $11 \%, 6$ mahasiswa atau 6\%, dan 3 mahasiswa atau 3\% lainnya mengatakan bahwa platform yang paling sering digunakan adalah market place, web resmi, dan search engine. Sehingga berdasarkan data tersebut media social menjadi platform favorit untuk mendapatkan informasi tentang fashion dibandingkan dengan market place, web resmi, maupun search engine. Hal ini karena media social merupakan platform yang bisa dikatan wajib untuk dimiliki di kalangan anak muda dalam hal ini yaitu mahasiswa. Seperti yang dikatakan oleh mahasiswa dari perbanas yang mengatakan dengan sangat yakin bahwa media sosial sebagai platform yang paling sering diakses : 
“....kalo ditanya yang paling sering dipaake ya sudah pasti medsos mba wong dikitdikit liat Instagram, bikin story gitu- gitu hahaha jadi yang paling sering ya media social..."

Bukan hanya itu media sosial yang sering digunakan oleh mahasiswa shopaholic pun juga sudah bisa diprediksi yaitu Instagram, hal ini dapat dilihat dari jumlah mahasiswa yang menggunakan dan memilih Instagram sebagai media sosial favorit yaitu sebanyak $80(80 \%)$ atau hampir semuanya, dan sisanya yaitu 20 (20\%) mahasiswa lebih memilih pinterest dibandingkan media sosial lainnya (line dan whatsapp). Meskipun line dan whatsap juga merupakanmedia sosial namun informasi yang didapatkan pun berbeda, antara media social yang satu dan lainnya. Berdasarkan survei dari (Wearesocial, Hootsuite, 2018) pengguna Instagram di Indonesia menjadi pengguna aktif instagram ke tiga setelah Amerika Serikat dan Brazil, yaitu dengan 55 juta pengguna. Selain itu Instagram memang merupakan media social yang sedang naik daun saat ini, berbeda dengan pinterest yang belum cukup terkenal apabila dibandingkn dengan media social Instagram. Hal ini terbukti dengan pendapat salah satu responden yang mengatakan bahwa :

“. kalo yang paling sering banget ya instagram mbak, sebenernya aku punya semua itu sosmed, tapi kalo instagram itu tiap hari pasti aku buka, beda sama yang lainnya, kayak line gitu buka juga sih, tapi ya kalo ada kepentingan aja, missal ada chat atau harus chat temen, tapi kalo yang aku jadiin apa yaaa hmm pokok tiap kali gabut tiap kali gaada kerjaan tiap kali butuh hiburan ya instagram mbak, lebih menarik gitu sih"

Dari beberapa market place yang ada, shopee merupakan market place dengan pengguna terbanyak yaitu sebanyak $82(82 \%)$ dari jumlah keseluruhan 100 mahasiswa shopaholic di Surabaya. Kemudian disusul oleh lazada sebagai market place dengan pengguna terbanyak kedua yaitu sebanyak 11 (11\%) mahasiswa. Selanjutnya sebanyak $5(5 \%)$ mahasiswa menggunakan tokopedia sebagai market place pilihan mereka, dan 2 mahasiswa lainnya market place yang paling sering digunakan yaitu bukalapak. Perbedaan ini bisa dibilang cukup jauh dengan presentase tersebut. Hal ini diakibatkan karena shopee memberikan tawaran yang sangat menguntungkan bagi kantong mahasiswa seperti misalnya ada games goyang shopee, gratis ongkir dan juga jaminan yang diberikan dari pihak shopee sendiri. Hal seperti itulah yang membuat mahasiswa memilih untuk menggunakan shopee daripada market place yang lainnya. Selain itu secara marketing shopee juga jauh lebih baik sehingga saat ini bisa dikatakan semua orang tahu shopee.

\section{Penyelesaian Masalah Shopaholic dalam Penemuan Informasi}

Berdasarkan hasil yang telah diperoleh menunjukkan tentang jenis masalah yang dialami mahasiswa shopaholic dalam penemuan informasi fashion, frekuensi masalah yang didapatkan mahasiswa shopaholic dalam penemuan informasi fashion, dan tindakan yang diambil mahasiswa shopaholic dalam menyelesaikan masalah yang mereka hadapi yakni dalam hal ini hambatan dalam penemuan informasi tentang fashion.

Melihat dari temuan diatas membuktikan bahwa mahasiswa mengalami kendala dalam kegiatannya untuk melakukan penemun informasi fashion, terbukti dari sejumlah $63 \%$ dari mereka mengalami hambatan. Adanya hambatan seperti ini membuat pengguna informasi menjadi tidak nyaman karena informasi yang mereka cari tidak ditemukan. Sehingga dengan demikian mahasiswa shopaholic harus memiliki opsi lain atau mencari cara lain untuk mendapatkan informasi yang mereka butuhkan. Adanya kendala dalam informasi terkait deskripsi barang atau produk seperti ini bisa dibilang cukup fatal, karena dari deskripsi itulah konsumen atau pengguna informasi akan mengetahui seperti apa barang atau produk tersebut. Dan hal ini juga akan berdampak pada minat pengguna sumber informasi untuk menggunakan sumber informasi yang tidak lengkap dan pun juga minat konsumen untuk melakukan pembelian atas barang tersebut. Keberhasilan seseorang dalampenemuan informasi ini dilatar belakangi oleh kebutuhan informasi mereka.

Mahasiswa ketika tidak mendapatkan informasi yang dicari akan melakukan kegiatan pencarian ulang karena ada kepuasan tersendiri ketika bisa mengatasinya dengan usaha sendiri. Mahasiswa juga melakukan penelusuran di ineternet seperti biasa karena dengan melakukan penelusuran di internet akan mempermudah mereka dalam menemukan informasi yang dibutuhkan, dan selain itu di internet kita juga bisa menemukan informasi yang lebih up to date. Dan sebaliknya apabila hanya menggunakan informasi yang telah ditemukan sebelumya, karena bisa saja informasi yang didapatkan tersebut tidak up to date, hal ini berlaku juga di catalog. Dan apabila harus berkonsultasi atau bertanya dulu kepada teman atau kerabat mungkin bisa saja tapi untuk waktu yang mendadak hal ini bukan pilihan yang tepat. 


\section{Simpulan}

Dalam penelitian yang berjudul "Perilaku Penemuan Informasi Tentang Fashion di Kalangan Mahasiswa Shopaholic Sebagai Gaya Hidup Hedonisme di Surabaya”, peneliti menemukan beberapa hal menarik di lapangan. Temuan menarik yang diperoleh dari lapangan tersebut dapat mendeskripsikan tentang kebiasaan mahasiswa, preferensi sumber informasi mahasiswa, serta penyelesaian masalah mahasiswa dalam penemuan informasi fashion. Dapat disimpulkan bahwa. Kebiasaan dalam penemuan informasi merupakan suatu bentuk kegiatan yang sering dilakukan mahasiswa shopaholic untuk menuju target atau tujuan yang ingin dicapai yaitu dalam melakukan penemuan informasi tentang fashion. Kebiasaan yang dilakukan mahasiswa shopaholic yaitu dengan cara mengakses media ataupun dengan cara- cara lain yang dipilih. Kebiasaan yang dilakukan mahasiswa shopaholic bisa dilihat beberapa elemen diantaranya yaitu informasi fashion yang paling sering dicari yaitu informasi tentang pakaian.. Selanjutnya yaitu mengakses tokoh idola merupakan bagian dari aktivitas penemuan informasi fashion yaitu yang di dominasi oleh selebgram, yang mana dlam hal ini selebgram sebagai idola atau panutan dalam berpakian. Mengenai intensitas mahasiswa dalam mengakses informasi fashion, mayoritas mahasiswa mengakses sosok idolanya sebanyak 1-2 kali dalam seminggu dengan durasi waktu 1- 2 jam. Tujuan merupakan salah satu elemen dasar dalam kebiasaan melakukan Penemuan informasi ialah untuk memperkaya pengetahuan tentang fashion yaitu sebanyak Preferensi sumber informasi mahasiswa shopaholic dalam penemuan informasi fashion Hal yang sering dilakukan mahasiswa yaitu dengan mengakses berbagai macam media untuk bisa mendapatkan informasi yang mereka butuhkan. Preferensi sumber informasi yang menjadi pilihan kebanyakan mahasiswa dalam penemuan informasi adalah media socia dan platform market place shopee dalam penemuan informasi fashion. Penyelesaian masalah merupakan cara yang dilakukan seseorang untuk memecahkan masalah dalam melakukan aktivitas pencarian informasi tentang fashion yang terdapat dalam perilaku penemuan informasi. Pada penelitian ini mayoritas mahasiswa (63\%) mengalami kendala/ hambatan dalam proses penemuaninformasi fashion. Dari pengalaman mahasiswa yang mengalami kendala tersebut, tiap mahasiswa memiliki intensitas yang berbeda dalam menemukan hambatan dan paling banyak mahasisiwa mnegalami hambatan 1-2 kali yaitu sebanyak $85 \%$.bentuk kendala yang pernah dialami pun juga berbeda-beda namun yang paling sering dialami yaitu terkait informasi barang/ produk (58\%).

Selanjutnya berkaitan dengan berhasil atau tidaknya penelusuran tersebut, 51\% mahasisiwa menyatakan berhasil karena informasi yang dibutuhkan bisa terpenuhi. Namun apabila tidak mendapatkan informasi sesuai kebutuhan maka mayoritas mahasiswa (43\%) akan melakukan kegiatan pencarian ulang dengan menggunakan sumber informasi lainnya. Akan tetapi sebagian sumber informasi ada yang mengharuskan untuk membayar terlebih dahulu, dan rupanya hal ini tidak mendapat respon baik dari mahasiswa, dimana hal ini bisa diliat berdasarkan data yang diperoleh yang menunjukkan $75 \%$ dari 100 mahasiswa mengaku tidak tertarik dengan sumber informasi yang memerlukan biaya karena menurut mereka masih banyak sumber informasi yang gratis dan relevan. Dan ketika membutuhkan informasi secara mendadak hal yang dilakukan oleh mayoritasmahasiswa (52\%) adalah dengan tetap melakukan penelusuran di internet seperti biasa. Nampaknya hal ini mendapat respon yang sama dari mahasiswa, dimana ketika membutuhkan informasi dalam waktu singkat hal yang dilakukan mahasisiwa yaitu dengan tetap melakukan penelusuran di internet (54\%)

\section{Referensi}

APJII. 2018. Hasil Survey Penetrasi dan Perilaku Pengguna Internet Indonesia 2017. Diakses pada https://www.apjii.or.id

Apriliana, Siska. 2017. Perilaku Penemuan InformasiTentang Fashion di Kalangan Remaja Putri Surabaya. Skripsi : Universitas Airlangga.

Aunurrahman. 2009. Belajar dan Pembelajaran. Bandung : Alfabeta.

Ceballos, L M. (2010). Analysis of The Stimuli of Londoners' Fashion- Oriented Impuls Buying Behaviour.

Journal International (Online) Vol.15 (87-97) 
Palimpsest: Journal of Information and Library Science Vol. 11, Issue 1, 2020, page 8-57

Gil, L. A., Kwon, K. N., Good, L. K. and Jhonson, L. W. 2011. Impact of Self On Attitudes Toward Luxury Brands Among Teens. Journal of Business Research. Vol. 65 (1425-

1433)

Hendraningrum, Retno., Susilo, Edy. (2004). Fashion dan Gaya Hidup : Identitas dan Komunikasi. Jurnal Ilmu Komunikasi Vol.6 No.2

Purwanti, Siska A. 2017. Perilaku Penemuan Informasi Tentang Fashion di Kalangan Remaja Putri Surabaya. Skripsi : Universitas Airlangga.

Savolainen, Reijo. 1995. Everyday Life Information Seeking: Approaching Information Seeking in the Context of "Way of Life". Tampere: University of Tampere Finlandia.

Sugiyono. 2012. Metode Penelitian Kuantitatif Kualitatif dan R\&D. Bandung : Alfabeta. Toth, M.

2014. The Role of Self-Concept in Consumer Behaviour.

Wearesocial, hootsuite. (2018). Digital in 2018 : Southeas Asia, A Study of Internet, Social Media, andMobile Use Througout the Region. Wearesocial. 